\title{
Malay Garden as Tourism Product in Malaysia
}

\author{
Ahmad Zamil Zakaria, Ismail Hafiz Salleh, \\ Mohd Sabrizaa Abd Rashid \\ Faculty of Architecture, Planning \& Surveying, \\ Universiti Teknologi MARA, \\ Seri Iskandar Campus, 32610 Perak, Malaysia \\ zamil227@perak.uitm.edu.my
}

\begin{abstract}
This study introduces the concept of Malay garden design in the eyes of tourists, particularly from the inside and outside the country. The objectives are to explain the relationship between cultural tourism and cultural landscape and how to produce the concept of landscape design as a new tourism product to become tourist attractions in Malaysia by using the old Malay manuscripts and an observation to the old houses of the Malay community in Peninsular Malaysia. Finally, researchers are ready to offer ideas to the planning and development of new tourism products based on local culture especially the Malays culture.
\end{abstract}

Keywords: Malay Gardens; Malay Landscape; Cultural Tourism; Tourism Products

eISSN 2514-751X @ 2018. The Authors. Published for AMER ABRA cE-Bs by e-International Publishing House, Ltd., UK. This is an open-access article under the CC BY-NC-ND license (http://creativecommons.org/licenses/by$n c-n d / 4.0 /$ ). Peer-review under responsibility of AMER (Association of Malaysian Environment-Behaviour Researchers), ABRA (Association of Behavioural Researchers on Asians) and CE-Bs (Centre for EnvironmentBehaviour Studies), Faculty of Architecture, Planning \& Surveying, Universiti Teknologi MARA, Malaysia DOI: https://doi.org/10.21834/aje-bs.v3i10.316 


\subsection{Introduction}

Currently, there are various design concepts in the field of landscape architecture. Among the well-known concept are the Japanese gardens, Balinese gardens, and the English gardens. Through this concept, the race art and culture being promoted to the wider community. Religious influence has distinguished between Malay gardens, Japanese gardens and Balinese gardens, as 'Malay gardens' influenced by Islam, 'Japanese gardens' influenced by Chinese Buddhist and 'Balinese gardens' is more influenced by Hinduism. The vernacular architecture has resulted from the merging of both socio-culture and climate of a place that evolved and developed due to the needs of the society Noor Hanita et al., 2012). Space in a public territory is for all inhabitants, and no one can declare his territory (Bambang et al., 2012). Landscape architecture scenarios in Malaysia presently more passionate about the contemporary design or mean of popular culture.

Strategy in promoting a new tourism product should strengthen either locally or internationally with full involvement of various parties including governments, private agencies, and the media. To encourage repeat visits by tourists to the area of new tourism products, it requires a variety of promotional methods, namely by introducing the concept of Malay gardens to the public and increase the construction of public parks based on the Malay garden design. The re-branding is very needed to check the products and elements of tourism in Malaysia. Products that considered in this re-branding should have unique characteristics which can show the identity or image to specific regions or localities. By rebranding the Malay garden design, it will also promote a traditional Malay way of life and local culture in Malaysia.

\subsection{Literature Review}

\subsection{The cultural landscape}

In the context of sociology, the term cultural landscape does not mean just to show the status of progress and sophistication of an area, but it could also reveal the identity, culture, social and the local economics. Boehm (1996), states that cultural landscape has a strong relationship with the field of anthropology and archeology. From this statement, researchers have concluded that the cultural landscape is able as a basic overview of the social structure, economy and culture of society who inhabit every corner of this earth.

\subsection{The cultural tourism}

The concept of cultural tourism is an extremely complicated because it will take every result of artificial subjects. McKercher \& Cros (2002) stated that the cultural tourism also occurs when tourists involvement in any activity, or something that can offer an infinite experience. Mclntosh \& Goeldner (1986), define cultural tourism as something that encompasses all aspects of the adventure which also involves the traveler to learn about the history of a place and the foreign community heritage or way of life and their current thinking. 


\subsection{A strong sense of place}

Heritage assets are important for every country in the world as it enlighten the history of the area (Aidatul et al., 2012). Referring to Harry (1985), an introduction to the unique character must continue to change and any changes supposed to design and cover as well as protect the uniqueness. The unique character or a great sense of place is often based on such things as architectural styles, an exclusive character of the natural environment. The emphasis on local culture spirit has an impact on a firm understanding of the Malay culture.

\subsection{The Quality of Life (QOL)}

Rusen (2011), mention the quality of life is a comprehensive concept which is concerned with the overall well-being of the society. Nowadays, the awareness and involvements of the community are very low because of the differences of ideology and culture. The scenarios caused difficulty for the community to unite. The concept of an image can be understood and define at the connection of branding and identity since the appearance is an important part of both (Muge et al., 2011).

\subsection{Strategic Tourism Destination Planning}

According to Inskeep (1991), a tourism destination which is strategic planning should be planned and designed to develop tourism optimally. The strategic planning included local income, employment generation and maintaining local control, at the same time as minimizing the pessimistic effects of tourism development, in particular on the environment and the social fabric of the society.

\subsection{Methodology}

The research processes are by using both quantitative and qualitative methods. The samples of criteria are:

1) Old Malay Manuscript (the hard and soft landscape elements existed) through secondary data using comparison study

2) Traditional Malay Village (4 zones in Peninsular Malaysia) - through site visit

3) The Malays houses that still maintain the values of authenticity - through site visits

\subsection{Old Malay Manuscripts}

The Hikayat Hang Tuah stated there we fifty-two (52) species of ornamental plants, forty-one (41) species of fruit trees and seven (7) types of plants classified as herbaceous plants and medicines. Sulalatus al-Salatin (Sejarah Melayu) has told the story of a Garden in Gunung Ledang. The garden full of bamboo species, there is trees around it and a variety of fruit trees and flowers. The garden also has a fish pond in the garden. The trees mainly refer to specific functions in the Malay community life at the time. Referring to the Bustan al-Salatin (Taman Raja-raja), there are forty-eight (48) different species of ornamental plants, twenty-six (26) 
different species of fruit trees, thirty-six (36) species of herbaceous plants and four (4) various species of trees. According to the Hikayat Abdullah, there are three (3) types of ornamental plant species, eighteen (18) different species of fruit trees, sixteen (16) species of herbaceous plants and four (4) various species of trees. The Malay Medical Heritage (Warisan Perubatan Melayu) mentions more than two hundred (200) species of plants used in Malay traditional medicine. It is the reason in choosing certain plants by referring to the functions and the belief of the Malays themselves. From the old note, researchers can find out where the beginnings of the early history of the use of plants in landscape design of the Malays.

\subsection{Malay garden concept today}

According to Lim (1987), the traditional Malay house compound divided into three main areas (front compound, side compound, and rear compound). The placement of landscape elements is based on their function in the compound. Through the observation, there are some differences in the concept of the Malay community garden, regarding geographical aspects, cultural of societal aspects, and the terrain elements. It used as a guideline to landscape designers to design Malay Garden. The differences in terms of visible geographic distribution zones in Peninsular Malaysia divided into four (4) zones which are the northern zone (Perlis, Kedah and Penang), middle zone (Perak, Selangor and Kuala Lumpur), the southern zone (Negeri Sembilan, Melaka and Johor) and the eastern zone (Kelantan, Terengganu and Pahang). It shows that culture has played a significant role in the design and arrangement of a garden in the Malay community. Refer photo $1-4$.

In the Malay community house compound commonly found plant such as Cocos nucifera (Coconut), Canangium odoratum (Cananga), Jasminum sambac (Jasmine), Vallaris glabra (Kesidang), Areca catechu (Areca nut), Cosmos violaceace (Ulam Raja), Cymbopogon nardus (Lemongrass), Languas galanga (Galangal), Curcuma domestica (Turmeric), Lawsonia inermis (Henna) and Zingiber officinale (Ginger).

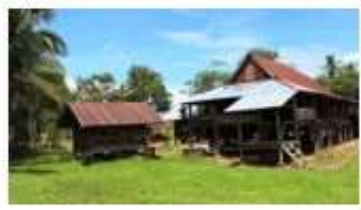

(a)

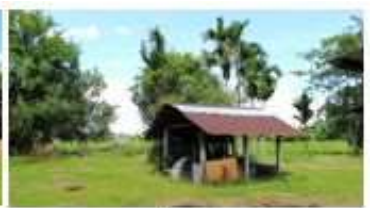

(b)

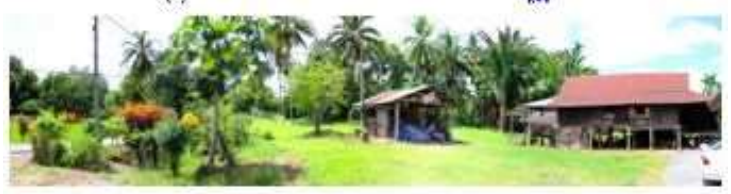

(c)

Photo $1(a-c)$ : Shown the concept of the Malay community garden at the northern zone, Kg. Gial, Mata Ayer, Perlis

(Source: Author, 2013) 


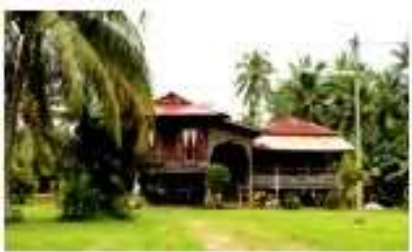

(a)

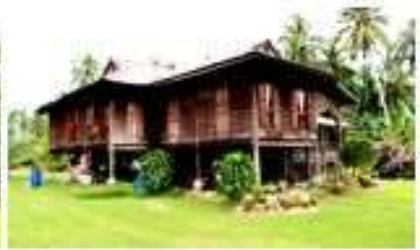

(b)

Photo $2(a-b)$ : Shown the concept of the Malay community garden in the middle zone, $\mathrm{Kg}$. Sg. Gulang - gulang, Tanjung Karang, Kuala Selangor, Selangor.

(Source: Author, 2013)

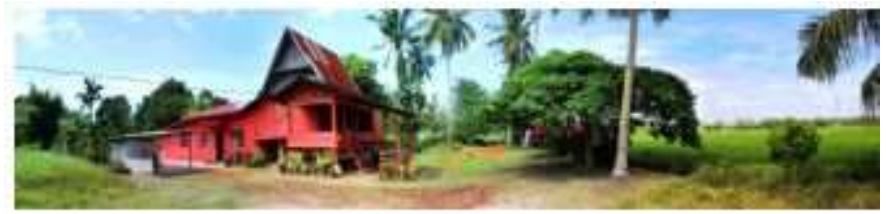

(a)

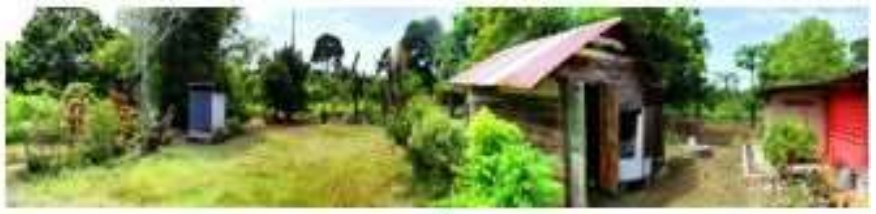

|b)

Photo $3(\mathrm{a}-\mathrm{b})$ : Shown the concept of the Malay community garden in the southern zone, $\mathrm{Kg}$. Simpang, Jln. Tanjung Pinang, Merlimau, Melaka.

(Source: Author, 2013)

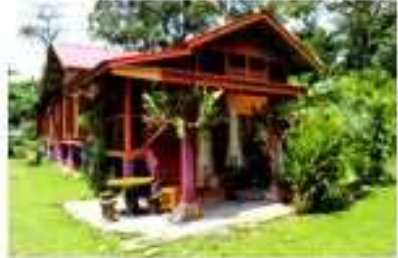

(a)

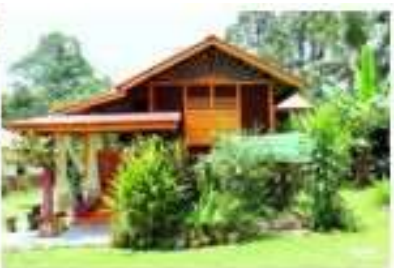

(b)

Photo $4(\mathrm{a}-\mathrm{b})$ : Shown the concept of the Malay community garden in the eastern zone, $\mathrm{Kg}$. Tanjung Gahai, Kuala Lipis, Pahang.

(Source: Author, 2013) 


\subsection{Results and Discussions}

The Malay garden concept is a research initiative in creating a garden and landscape design concept exclusive to the Malays in Peninsular Malaysia. In general, traditional Malay people develop their garden to meet harmony with the environment, including the idea, activities, and functions. There are similarities in the use of plant species in the Malay community life. For example, the Malays use the fragrant plants, herbs and medicines as major plants for their home surroundings. The Malay people appreciate the beauty of house garden or the garden of the palace planted with a variety of plants, particularly the type of fragrance plants. The data shown below are the elements of the landscape and garden that will form the basis of The Malay garden design model (Table 1). Table 2 listed the seven most often cited plant species in the old Malay manuscripts.

Table 1: List of landscape furniture observed by the author and recorded in the research papers done by researchers in the past about the Malay garden in the Malay Archipelago.

\begin{tabular}{|c|c|c|}
\hline No. & $\begin{array}{l}\text { Local Name (as be called by local } \\
\text { people) }\end{array}$ & English name \\
\hline 1. & Ampaian & Suspension \\
\hline 2. & Bangsal / Sulap & Barn \\
\hline 3. & Buaian & Tree swings \\
\hline 4. & Gerbang & Arch \\
\hline 5. & Guri & $\begin{array}{l}\text { Guri (smaller than common traditional Malay water } \\
\text { vessel) }\end{array}$ \\
\hline 6. & Jamban / Tandas & Latrine \\
\hline 7. & Jamung andang / Kandil & Torch \\
\hline 8. & Kepok padi / Jelapang & Paddy store \\
\hline 9. & Kolah & Water tank \\
\hline 10. & Kolam & Pond \\
\hline 11. & Pagar & Fence \\
\hline 12. & Pangkin & Resting hut (usually without shelter) \\
\hline 13. & Pasu bunga & Flower pot \\
\hline 14. & Pelantar & Open timber platform (usually for washing clothes) \\
\hline 15. & Perigi & Well \\
\hline 16. & Perun & Dump site \\
\hline 17. & Reban & Hen coop \\
\hline 18. & Tempayan & Water vessel \\
\hline 19. & Titi & Log bridge (usually made from Areca nut trunk) \\
\hline 20. & Wakaf & Gazebo \\
\hline
\end{tabular}

(Source: Zamil et al., 2013)

Table 2: List of the most often cited plant species in the old Malay manuscripts.

\begin{tabular}{clll}
\hline No. & $\begin{array}{lll}\text { Plants Species } \\
\text { Local Name }\end{array}$ & Botanical Name & Description \\
\hline 1 & Bunga gandasuli/gandasuli & $\begin{array}{l}\text { Hedychium } \\
\text { coronarium }\end{array}$ & $\mathbf{4}$ (BaS, TOHT, SaS, TMM) \\
2 & Kelapa/bunga kelapa/nyiur/nyior & Cocos nucifera & $\mathbf{5}$ (BaS, TOA, TOHT, TOI, TOMM) \\
3 & & & \\
94 & & &
\end{tabular}


Zakaria, A.Z., et.al. / Asian Journal of Environment-Behaviour Studies (ajE-Bs), 3(10) Sep / Oct 2018 (p89-98)

\begin{tabular}{|c|c|c|c|}
\hline & $\begin{array}{l}\text { Bunga delima/bunga delima } \\
\text { wanta/delima }\end{array}$ & Punica granatum & $\begin{array}{l}6 \text { (BaS, TOHT, TOI, TOMM, SaS, } \\
\text { TMM) }\end{array}$ \\
\hline 4 & Pinang & Areca catechu & 5 (BaS, TOA, TOHT, TOI, TOMM) \\
\hline 5 & Langsat & Lansium domesticum & 4 (BaS, TOA, TOHT, TMM) \\
\hline 6 & Anggur & Vitis spp. & 4 (BaS, TOA, TOHT, TOI) \\
\hline 7 & Gaharu & $\begin{array}{l}\text { Aquilaria } \\
\text { malaccensis }\end{array}$ & 4 (BaS, TOA, TOI, TMM) \\
\hline
\end{tabular}

Legend; 1. Bustan al-Salatin -The Garden of Kings (BaS), 2. Tale of Abdullah (TOA), 3. Tale of Hang Tuah (TOHT), 4. Tale of Inderaputera (TOI), 5. Tale of Merong Mahawangsa (TOM), 6. Sulalatus al-Salatin (SaS), 7. Traditional Malay Medicine (TMM).

(Source: Author, 2013)

\section{How to promote a cultural tourism product? - "The concept of the Malay garden design."}

From the data shown previously, the Malay garden in Malaysia has its identity, characteristic and it can be an advantage to promote as a tourism product. There are several methods to promote the concept of the Malay garden design:

1. Produced design model to become a complete guideline to landscape designers regarding the principles and elements of design, philosophy, and functions. The model should be designed by the National Landscape Department (NLD) with collaborations from the various agencies involved with the heritage and culture of Malaysia.

2. The model of Malay garden concept design should get recognition from the local cultural experts, and the presented concept is representative of the Malay community landscape.

3. Need to have an example of Malay Garden design. Today, Taman Mini Malaysia in Melaka becomes as an information provider for Malay architecture, with showcasing models of several of the Malay houses. Unfortunately, there are lacks of information about the Malays landscape displayed to the public due to the construction of the traditional Malays landscape not included.

4. The Malay gardens have promoted as the country's new tourism products in the magazines, internet resources and tourist brochures to attract visitors.

5. Ministry of Tourism and Culture (KPKM) and the Ministry of Communications and Multimedia (KMM) and the Ministry of Urban Wellbeing, Housing and Local Government (KPKT) need to work together in promoting landscape designers to use the concept of The Malay garden design in their landscape design.

6. Recognize the landscape designers who are using the concept of The Malay garden design, as a means providing incentives to promote The Malay landscape to the Malaysian community and tourists.

7. National Landscape Department (NLD) and the Institute of Landscape Architects Malaysia (ILAM) responsible for making sure that the students majoring in landscape 
architecture at universities and colleges in Malaysia been introduced the concept of The Malay garden design.

8. Organizing events related to garden and plant in Malaysia such as LAMAN and FLORIA Putrajaya has become a catalyst for progress in the Malaysian landscape. Indirectly, these events have become a huge event and have attracted many visitors and tourists.

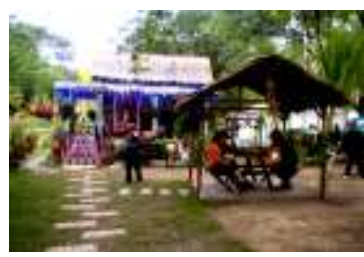

(a)

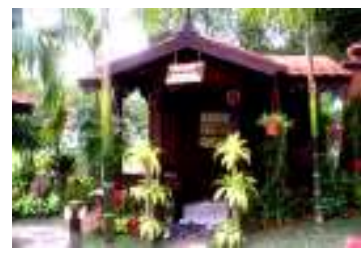

(b)

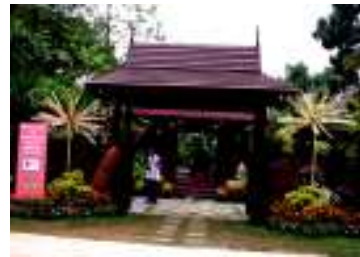

(c)

Photo $5(\mathrm{a}-\mathrm{c})$ : Show an example of displaying Traditional Malay Garden Design Concept to the public at Festival Landskap Dan Taman Antarabangsa | LAMAN 2006 - 2008.

(Source: Author, 2013)

\subsection{Conclusion}

For this study, researchers have outlined some interests which include the study of the Malay culture to promote internationally. Besides, the concept of the Malay gardens exclusively to the Malaysian Malay community can encourage the expansion of the landscape architecture field in Malaysia, particularly in areas of tourist attraction to showcase Malaysia's uniqueness. Potentials of each plant and landscape furniture need more highlighted, by that we may quickly commercialize and eventually will be a source of income to the Malaysian society as a result of the sale of the plants and hard landscape elements. Besides that, it is also expected to increase the number of tourists as well as being an asset and identity of the Malay community. A public park that displays the culture of the local community and conservation of old houses Malay community has shown positive effects in promoting cultural tourism products. By having the Malay gardens probable, it will become a national cultural heritage and is widely used in developing the public parks in Malaysia.

\section{Acknowledgement}

We would like to express our gratitude to the Research Management Centre (RMC), Universiti Teknologi MARA. Special thanks to our sponsors of MOSTI (ScienceFund) for providing an adequate provision in this project. This research cannot be successful if not getting the invaluable support of the Centre for Knowledge and Understanding of Tropical Architecture and Interior (KUTAI) and Taman Alam Melayu Nusantara (T.A.M.A.N), where the instruction, discussion and exchange of opinions helped us the success of this research. 


\section{References}

Samad Ahmad (editor) (1982). Warisan Perubatan Melayu, Kuala Lumpur, Dewan Bahasa dan Pustaka.

Samad Ahmad (editor) (1996). Sulalatus Salatin - Sejarah Melayu, Kuala Lumpur, Dewan Bahasa dan Pustaka.

Ahmad Zamil Zakaria, Ismail Hafiz Salleh and Mohd Sabrizaa Abd. Rashid (2013). Landscape Furniture Present in the Ancient Malay Garden According to Old Manuscripts and their Effects on the Formation of Malay Garden Design Concept Model in Malaysia, Procedia - Social and Behavioral Sciences, Elsevier, Vol. 91, Elsevier Ltd.

Ahmad Zamil Zakaria, Ismail Hafiz Salleh and Mohd Sabrizaa Abdul Rashid (2012). Plants Present In The Ancient Malay Garden According To Old Manuscripts And Their Effects On The Formation Of A Malay Garden Design Model In Malaysia, Simpora9, Universiti Teknologi MARA (Perak).

Aidatul, F. B., Nooridayu, A. Y. and Norajlin, J. (2012). Managing Heritage Assets: Issues, Challenges And The Future Of Historic Bukit Jugra, Selangor, AicE-BS 2012 Cairo, Procedia Social and behavioral Sciences Vol. 68, Elsevier Ltd.

Ali Ahmad (editor) (2000). Hikayat Inderaputera, Kuala Lumpur, Dewan Bahasa dan Pustaka.

Amin Sweeney (editor) (2006). Karya Lengkap Abdullah bin Abdul Kadir Munsyi, Jilid 3: Hikayat Abdullah, Jakarta: Kepustakaan Populer Gramedia \& École française dExtreme-Orient.

Bambang, S., Budi, S., and Hermin, W. (2012). In Search Of The Power Of Javanese Culture Against The Cultural Urbanization In Kotagede, Yogyakarta-Indonesia, AicE-BS 2012 Cairo, Procedia Social and behavioral Sciences Vol. 68, Elsevier Ltd.

Boehm, R.G (1996). Association of American Geographers: Cultural and Human Geography, (Online) retrieved on 15 March2013 http://www.aag.org/Careers/Cultural_Human_Geography.html

Hamzah Hamdani (2007). Hikayat Abdullah, PTS Publications, Malaysia.

Harry, L.G., (1985). Maintaining The Spirit of Place -A Process for the Preservation of Town Character, PDA Publishers Corporation, Mesa, Arizona.

Jelani Harun (editor) (2004). Bustan al-Salatin, Kuala Lumpur: Dewan Bahasa dan Pustaka.

Kasim Ahmad (1975). Hikayat Hang Tuah: Kota Melaka, Kuala Lumpur, Dewan Bahasa dan Pustaka.

Lim Jee Yuan (1987). The Malay House: Rediscovering Malaysia's Indigenous Shelter System, Institut Masyarakat.

McIntosh, R.W., Goeldner, C.R. and Ritchie, J.R.B. (1995). Tourism: Principles, Practices, Philosophies, $7^{\text {th }}$ Edition, John Wiley \& Sons, Inc., New York.

McKercher, B and Du Cros, H. (2002). The Partnership Between Tourism And Cultural Heritage Management, The Haworth Hospitality Press, London and Oxford, New York.

Muge, R., Naciye, D. and Mukaddes, F. (2011). City Branding and Identity, AicEs-BS 2011 Famagusta, Procedia Social and behavioral Sciences Vol. 35, Elsevier Ltd.

Noor Hanita, A.M., Hokoi, S. and Nozomi, T. (2012). Vernacular Wisdom: The Basis Of Formulating Compatible Living Environment In Oman, AicE-BS 2012 Cairo, Procedia Social and behavioral Sciences Vol. 68, Elsevier Ltd. 
Rusen, K. (2011). The Quality of Life and the Environment, AicEs-BS 2011 Famagusta, Procedia Social and behavioral Sciences Vol. 35, Elsevier Ltd.

Siti Hawa Salleh (1998). Hikayat Merong Mahawangsa, Kuala Lumpur, Yayasan Karyawan dan Penerbit Universiti Malaya.

Siti Hawa Salleh (editor) (1992). Bustan al-Salatin, Kuala Lumpur: Dewan Bahasa dan Pustaka. 